\title{
MASTERY AND SLAVERY
}

The claim that Aristotle thinks household activities ought to educate members in virtue appears to be problematic in view of the fact that he includes mastery and slavery among those activities. Neither commanding physical work nor doing it for another seems to be edifying. As I noted in Chapter 1, Arendt argues that mastery in Aristotle's view requires even force and violence. Moreover, according to her, Aristotle believes that human beings "are entitled to violence toward others" because "violence is the prepolitical act of liberating oneself from the necessity of life for the freedom of world." 1 Thus Arendt implies that Aristotle justifies not only the physical subjection but the moral and spiritual degradation of slaves. ${ }^{2}$ "The slave's degradation was a blow of fate and a fate worse than death, because it carried with it a metamorphosis of man into something akin to a tame animal"; life as well as the good life requires demoting some human beings to a nonhuman status. ${ }^{3}$

1 The Human Condition (Chicago: University of Chicago Press, 1958), 31, emphasis added; see also 32, 81-84, 119, 121. According to Mary P. Nichols, Aristotle depicts slavery as violent, but also as unjust; see "The Good Life, Slavery, and Acquisition: Aristotle's Introduction to Politics," Interpretation: A Journal of Political Philosophy 2, no. 2 (1983), 171, 176.

2 Put otherwise, the slave is subjected by both physical necessity and human beings (Human Condition, 31).

3 Ibid., 83-84. Arendt does not make clear everywhere in her account of slavery in Human Condition whether she is describing the ancient practice of slavery or Greek philosophers' conceptions of slavery. Indeed, her discussion as a whole implies that the philosophical account was meant to be a justification of the historical practice and otherwise followed Greek public opinion. 
Other scholars point out that Aristotle's theory of slavery is inconsistent because it indicates that slaves are both human and subhuman: Aristotle declares that slaves are human to signify their usefulness, but he does not technically classify them as human to justify their enslavement. According to these scholars, Aristotle's justification of natural slavery is, either intentionally or unintentionally, unconvincing because it fails to prove the existence of natural slaves. ${ }^{4}$

In this chapter I challenge both Arendt's rendition of Aristotle's view of the nature of slavery and the charge that Aristotle fails to show the naturalness of slaves and thus the justness of slavery. I argue that, according to him, the ideal or natural master-slave relationship is (1) private and domestic; (2) between human beings who are naturally unequal; (3) physically advantageous to both parties; and (4) edifying to both parties.

\section{Slavery: A Nonpublic, Domestic PRACTICE}

I establish in this chapter that mastery and slavery are, according to Aristotle, private in the sense of being activities that cultivate unpoliticized virtue in their agents. But it should also be made clear that the slavery Aristotle is justifying is private in the more narrow and usual sense: he thinks that slaves, or at least most slaves, should be owned by individual households, not by the community. In the best regime, land-owning citizens would own "private hands," while the regime would own hands to work on the common farm land (Pol 1330a30-31, 1278a11-13); but the territory owned privately would be twice the size of the common farm land (1330a9-15), which could mean that there should be more privately owned than publicly owned slaves. This possibility, plus the fact that Aristotle's treatment of household slavery in Book I

4 See, for example, E. Barker, The Political Thought of Plato and Aristotle (New York: Dover, 1959), 367-68, 372; W. D. Ross, Aristotle: A Complete Exposition of His Works and Thought (New York: Meridian, 1959), 235; R. G. Mulgan, Aristotle's Political Theory: An Introduction for Students of Political Theory (Oxford: Clarendon, 1977), 4044; Nichols, "Good Life," 171, 175-76. Barker argues that Aristotle is aware of and compensates for (but does not resolve) the inconsistencies in his account; Nichols, unlike the others, contends that Aristotle fails intentionally to demonstrate the existence of natural slaves. 
surpasses in length and detail all mention of public slavery in the Politics, indicates that he is a partisan more of private than public ownership of slaves.

Furthermore, since Aristotle observes that people take less care of what is owned by many (Pol 1261b33-34), it may be inferred that he thinks it would be more advantageous to the slave to be privately rather than publicly owned, 5 and more advantageous to the master to have fewer slaves (fewer slaves would be less inclined to slight their duties "on the grounds that someone else is taking thought for them"; 1261b35-36). Masters would also benefit from private ownership in that their servants would be able to render them a wider range of services (for example, constant cooking and child care) than they would be able to if they were housed and supervised by the city.

Finally, as I show below, by characterizing slaves not only as private but as domestics (as opposed to field hands), sharing in the life of the family, Aristotle gives us reason to think that each household should have at most a few slaves.

These points suggest that Aristotle's ideal system of slavery does not presuppose nature providing more slaves than free persons or, in other words, does not presuppose an unlikely ratio of slavish to free natures.

\section{Natural Slaves, Animals, AND THE SLAVISH}

Aristotle's definition of the natural slave also suggests, perhaps, that a sufficiency of slaves may exist: natural slaves differ from free persons in being able to participate in reason (koinōnōn logou) only by perceiving it; they do not have, in the sense of 'have charge of' or have completely, reason ( $\mathrm{Pol} 1254 \mathrm{~b} 22-23)$. More precisely, not having the deliberative element (to bouleutikon), they cannot deliberate (Pol 1260a12). Aristotle explains what he means by passive reason in Book VI of the Nicomachean Ethics, where he identifies the intellectual virtues. Among these virtues is a naturally endowed faculty (1143b6-7) that he calls understanding (sunesis), the func-

5 By receiving more or better food, clothing, and housing, a private slave in effect receives more pay (Oec 1344b4; note 15 below explains the composition of Book I of the Oeconomica). 
tion of which is "to judge what someone else says" (1143a12, 1415). Apparently, then, the person who has understanding can comprehend speech and can furthermore distinguish between speech in the service of good and that in the service of evil. It would, then, be "odd" if slaves did not have moral virtues of some sort, given that they "are human beings and participate in reason" (Pol 1259b21-28). What distinguishes natural slaves from free persons, however, is that, having only understanding, they cannot reason on their own and thus cannot conceive or define what is good and bad. 6

But is this in fact Aristotle's definition of the natural slave? He declares also that "those who are as different [from other men] as the soul from the body or man from beast-and they are in this state if their work is the use of the body, and if this is the best that can come from them-are slaves by nature" (Pol 1254b16-19). It should be noticed, however, that Aristotle qualifies or softens the first set of implied comparisons (master $=$ soul, slave $=$ body) with another (man, beast), presenting two inexact threefold comparisons $($ master $=$ soul $=$ man, slave $=$ body $=$ beast). Thus it is clear at least that he does not mean to suggest that a master is pure soul. And since it is possible that he thinks animals have the capac-

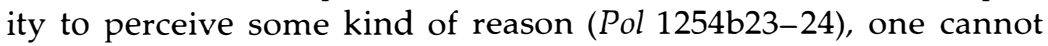
with certainty interpret him to mean that a slave is simply a body. ${ }^{7}$ If the spirit of the statement is that 'a master and a slave are as far apart as a soul and a body or, more precisely, as a man and an animal,' then he could be claiming that there are human beings who, like animals, are less than fully rational but have souls or a kind of moral disposition. ${ }^{8}$

6 See note 29.

7 At $1254 \mathrm{~b} 23-24$ there is a problem with the text. If one reads log $\bar{Q}$ with Alois Dreizehnter, the translation is "The other animals do not obey reason, though perceiving it, but their feelings." If one reads logou with H. Rackham and Carnes Lord, the translation is "The other animals, not perceiving reason, obey their feelings." The manuscript with logou belongs to the family of the best manuscripts, though Lord says that the more usual translation is produced by Dreizehnter's reading, which I follow; see Aristotle: The Politics, trans. Carnes Lord (Chicago: University of Chicago Press, 1984), 26, 248 n. 16.

8 On this reading, Aristotle does not create the difficulty that many scholars contend he creates. They correctly point out that he says that a slave is a human being and defines a human being as a rational and political (that is, social) animal. But, claiming that he defines a natural slave as simply a body or (at Pol 1254b23) as someone who does not possess reason at all, they wrongly insist that he means that natural slavery rests on a distinction of kind rather than of degree. They imply that 
Aristotle's claims that animals have a kind of prudence (NE 1141a27-28) and even a divine element (ti theion) (PA 641a19, GA 737a10) suggest even more strongly that he does not intend, in comparing slaves to animals, to degrade slaves as much as to show their different nature. ${ }^{9}$ As one scholar notes, animals and human beings represent a continuum according to Aristotle: "Taken as a whole, the animal world is found to present a graduated scale of perfection rising to man as its culminating point." 10 What is more, Aristotle implies that on a moral (not structural and functional) spectrum some animals surpass some human beings. Noble animals, sensing moral qualities, are more virtuous than vulgar human beings and are in this way comparable to natural slaves.

By characterizing the natural slave as having and being able to detect moral qualities, Aristotle seems to be implying a distinction between the natural slave (phusei doulos) (Pol 1254b21) and the vulgar or slavish (andrapodon) (Met 1075a21, Pol 1277a37). The slavish cannot be very responsible and do not respond to admonition (Met 1075a22, Pol 1260b6-7); by contrast, those who have understanding can recognize what is prudent (NE 1143a6-7, 14-15) and so obey it (Oec 1344a26). ${ }^{11}$ Apparently, then, consistent with the plan of the

\footnotetext{
Aristotle cannot mean that a slave is someone who has partial reason, which is inconceivable, contravenes logic: "That reason should be present even in an imperfect form means a potentiality of reason in its fulness" (Barker, Political Thought, 365). Why? One would not claim that a deformed arm has the potential to be a complete arm. The comparison is indeed apt, for just as a deformed arm may perform some of the functions of a complete arm, imperfect reason may perceive some of what complete reason perceives. Both an imperfect arm and imperfect reason have a potential, but it is their own, not that of their complete counterparts. The eidos of a species is not the same as the telos of an individual member of it; "everything is defined by its work and its capacity (tę dunamei)" (Pol 1253a23), and capacity is determined less by the species or genus than by the parents or immediate ancestors (GA 767b30-768a3). The difference between superior and inferior members of a species is not that the superior can and the inferior cannot actualize a common telos, but that "all inferior things reach their end [or perfection; to telos] more quickly" (GA 775a20-23). If Aristotle means that the natural slave has undeveloped rather than stunted reason, then why does he distinguish between the slave's reason and the child's, which he says is undeveloped (ateles) (Pol 1260a12$14)$ ? He of course recognizes the difference between being not yet mature and being maimed (see, for example, DA 425a10-11).

9 This is not to say that Aristotle never uses 'animal' in the negative sense (connoting amorality or immorality).

10 John Leofric Stocks, Aristotelianism (Boston: Marshall Jones, 1925), 64; see also 65-77; on Aristotle's conception of the ordered beauty and unity of nature generally, see $62-80$.

11 See also Politics, trans. Lord, 248 n. 16.
} 
Politics, Aristotle is discussing ideal slaves and the ideal sort of slavery. ${ }^{12}$

\section{The Master-Slave Relationship}

The finding that natural slaves are morally sensitive and comprehending casts doubt on the claim that Aristotle thinks masters should control them with force and violence. This doubt becomes more reasonable on consideration of other points of the section of the Politics (I.4-7) dealing especially with slavery. ${ }^{13}$ In chapter 4 he designates a slave as a "possession" belonging wholly to the master (1254a9-13), but in Book II he observes that human beings care most for what is their own (1261b34, 1262b22-23); thus masters look after their slaves. Following up on chapter 5 's suggestion that the slave perceives and obeys reason not force, he expounds in chapter 6 that the status of the natural slave derives from ill birth rather than from being captured in war. Similarly, in chapter 7 he explains that mastery (despoteia) is not the same as "expertise in acquiring slaves," which is "like a certain kind of expertise in war or hunting" (1255b37-39). Moreover, he characterizes a natural master-slave relationship as mutually affectionate (1255b12-14, 1260a39-40): one can be friends with a slave at least insofar as the latter is a human being, meaning, apparently, to the extent that the slave is morally virtuous (NE 1161b5-8).

The Duties of a Master

If not with force and violence, how should masters rule slaves? According to Aristotle, they should do so by including servants in the home, training them, and teaching them moral virtue to the

12 See the Appendix, "The Composition of the Politics," pp. 221-26.

13 In chapter 3 Aristotle introduces the subject of slavery with a passage that points toward my thesis and works against Arendt's (1253b14-22): "Let us speak first about master and slave, so that we may see . . . whether we cannot acquire something in the way of knowledge about these things that is better than current conceptions." He proceeds to give two examples of such conceptions. The first is that there is no difference among types of rule, which he has already denied at 1252a7-9. The second popular view holds that mastery is contrary to nature: "In their view the distinction of master and slave is due to law or convention; there is no natural difference between them: the relation of master and slave is based on force, and being so based has no warrant in justice." It is clear here that he disagrees with both conceptions. 
extent possible. To carry out these duties, a master should have the proper disposition toward each slave: she should regard a slave as part of herself, realize that she and the slave share the common goal of maximizing the self-sufficiency of the household, and recognize that therefore ruling badly would disserve them both ( $\mathrm{Pol}$ 1255b9-11, 1254a27-28, 1252b31-1253a1). ${ }^{14}$ A master should thus rule over a servant with justice (NE 1134b10-12, 1138b7-8). Xenophon, whose views on household management were shown, probably by Theophrastus, to agree largely with Aristotle's, conveys similarly that one should treat servants fairly in order to elicit their cooperation. ${ }^{15}$ Xenophon's chief interlocutor in the Oeconomicus, Ischomachus, whom the interlocutor Socrates deems to be the greatest estate manager in all of Athens, convinces Socrates that the treatment of servants can make the difference between their continually wanting to run away and their staying at their posts and working. ${ }^{16}$ Offering specific advice, Ischomachus recommends that one allow all but the most difficult servants to have families, for this increases their loyalty (Oec 1344b17). At the same time, a master should make servants feel a part of the master's family by sharing with them joys and troubles; this too wins their loyalty. ${ }^{17}$ The master should share also her things in order to en-

14 Aristotle indicates that the free woman of a household should manage its property (Pol 1277b24-25, 1264b1-3). Because he also gives the free male of the household authority over the children and reciprocal authority over his wife (see Chapter 3, "An Educated Being: A Parent?" and "A Pairing Being: A Wife"), he seems to mean when he says that the household should be "run by one alone" (Pol 1255b19) not that the male should manage everything but that he should be the sole delegator of authority.

15 The first book of the Aristotelian Oeconomica was largely derived from Xenophon's Oeconomicus and Aristotle's Politics, probably by Aristotle's successor as head of the Peripatetic school; see the Introduction to Aristotle's Oeconomica (Loeb Classical Library, 1935), by G. Cyril Armstrong, 323.

16 Xenophon, Oeconomicus (Loeb Classical Library, 1923), 380-83, 412-13. Xenophon apparently puts his own views into the mouths of both Socrates and Ischomachus in this dialogue; see E. C. Marchant's Introduction, ibid., xxiv.

17 Ibid., 440-43. Barker makes a similar point to the one I am implying: "The slavery which Aristotle contemplates is one which has lost half its sting. It is a slavery in which the slave is admitted into the life of the family, and in which he becomes imbued with the tone and character of the family in which he lives. . . . He is a member of this lesser association, sharing in its full moral life, as a real 'part' . . . and not as a mere 'condition'" (Political Thought, 370). See also Abram N. Shulsky, "The 'Infrastructure' of Aristotle's Politics," (Ph.D. diss., University of Chicago, 1972), 41. Aristotle argues that natural slaves should be domestic servants in part because he thinks that masters should regard them as more than living tools. Ross contends that Aristotle conceives the slave as a domestic and only as a living tool (Aristotle, 233, 235). 
dear her servant to her. Sharing, rather than exchanging, property is fitting in fact among all household members (Pol 1257a20-22). Ischomachus notes that, although servants do not own anything in the household, they may use it with the master's consent; and in the limited sense of tending to the household's property, they have a share in it. ${ }^{18}$

The master should also teach skills to her servants or, ideally, pay others to do so (Pol 1255b24-27), in order to promote the wellbeing of both the household and the servants. Ischomachus charges his wife with the responsibility of teaching weaving, baking, housekeeping, and serving to the servants. ${ }^{19}$ Seeing that the servants learn skills is important also because, when skilled, servants may easily be commanded by a master or an overseer, freeing the master for politics and philosophy (1255b33-37). ${ }^{20}$

What the master cannot delegate is her duty to instill in servants the self-restraint and fortitude they need to do their work ( $\mathrm{Pol}$ 1260a15-17, 35-36, b3-4). ${ }^{21}$ Simply using or commanding servants is not edifying, but leading them in moral matters apparently is ( $\mathrm{Pol}$ 1255b22-23, 31-36, 1325a25-27, 1260b3-5). ${ }^{22}$ Indeed, Xenophon implies, Ischomachus acquired his gentlemanliness not by participating in the Athenian democracy but by such household activities as guiding "the servants into the path of justice with the aid of maxims drawn from the laws of Draco and Solon."23

Perhaps with servile virtues (Pol 1260a23-24) slaves can understand what it means to be loyal, honest, and conscientious with respect to their tasks, but they cannot generalize these concepts. ${ }^{24}$ Thus, Ischomachus teaches his servants honesty by appealing to

18 Xenophon, Oeconomicus, 444-45.

19 Ibid., 426-27, 450-51; Ischomachus indicates that both he and his wife select and teach the servants moral virtue, but he charges her with overseeing them and the household generally $(389,414-27,442-45)$; Xenophon and Aristotle seem to agree that the free woman should manage the household.

20 For Aristotle's views on women as citizens and philosophers, see Chapter 3, “A Speaking Being: A Citizen?" pp. 59-61, and "An Intellectual Being: A Philosopher?" pp. 61-65.

21 See also The Politics of Aristotle, trans. Ernest Barker (Oxford: Clarendon, 1968), 37 n. 4, and Barker, Political Thought, 369-70.

22 The servants' need for personal and moral guidance may also account in part for the fact that "in household service many attendants sometimes do a worse job than fewer" (Pol 1261b36-38).

23 Oeconomicus, 410-13, 476-77; see also 442-43.

$24 \mathrm{Or}$, as Barker says, "[the slave], like the other members of the household, shares in its moral life according to his place and in his degree" (Political Thought, 370). 
their self-interest and aims "to make [them] upright in the matters that pass through their hands." 25 In sum, the primary aim of mastery on this account is to maximize the moral virtue of slaves. ${ }^{26}$

\section{Slaves: Unequal Natures, Unequal Treatment}

Treating servants well, even teaching them skills and virtue, does not guarantee their cooperation. Some human beings, though nature intends for them to be ruled by others, "refuse to obey that intention." Against these, Aristotle claims, nature justifies using the art of war (Pol 1256b24-26). Since it is always advantageous for superior to rule inferior, a slavish person unwilling to be ruled by someone more capable fails to perceive his or her own good and what is reasonable, just, and noble ( $\mathrm{Pol} 1325 \mathrm{~b} 10-12)$. Such a person is more slavish than other slaves (Oec 1344a26), for a natural slave "is capable of belonging to another" (Pol 1254b20-21). ${ }^{27}$ In short, being variously disposed to being ruled means that slaves are variously able to understand what is reasonable. Ischomachus recognizes this, pointing out to Socrates the differences among servants: some are discreet, useful, honest, loyal, temperate in eating and wine drinking and sleeping, modest with men, ambitious, attentive to their duties, possessing good memories, obliging, eager for the improvement of the master's estate (or, what is the same, "covetous of gain in a moderate degree"); but others are rogues prone to mischief, drunkards, sluggards, desperately in love, worthless, incorrigibly greedy, and persistently dishonest. ${ }^{28}$

Both Aristotle and Xenophon conclude therefore that masters should treat slaves variously (Oec 1344a29-30, 35-b11). Masters should distribute work according to ability and disposition, for example, giving the trustworthy more responsibility, such as child care (Pol 1277a37-38, Oec 1344a26). Yet a master should approach all slaves in the same way: trying initially, with patience or tem-

25 Oeconomicus, 476-77.

26 See also Barker, Political Thought, 368-70. Household management is concerned with instilling virtue more in the free household members than in the slaves (Pol 1259b18-21), but evidently because the slaves have less capacity for it.

27 It is misleading, then, to say as Ross and Mulgan do that Aristotle divides the human race in two (Aristotle, 235; Political Theory, 43). There are in fact two reasons slaves differ in their dispositions. Each is born, like every living thing, with a unique "internal principle." And the circumstances in which they live either enhance or impede the exercise of their virtues. Thus, "the same completion is not reached from every principle" (Ph 199b17-18).

28 Xenophon, Oeconomicus, 426-29, 440-43, 466-69, 474-77. 
perance, to reason with or encourage a slave before resorting to command or force. ${ }^{29}$ Indeed, one should treat a slave more like a free adult than like a child ( $\mathrm{Pol} 1260 \mathrm{~b} 5-7,1256 \mathrm{~b} 26) .{ }^{30}$ In fact, "it is better to hold out freedom as a reward for all slaves" (Pol 1330a3233); masters should provide an incentive for all slaves to work well (Oec 1344b15-16) and thus better themselves. Freedom should be conditional on their meeting the standards of conduct and performance that nonslaves meet. ${ }^{31}$

Ischomachus and his wife seem to be exemplary masters from Aristotle's point of view. They treat their servants according to merit: "I don't choose to put the deserving on a level with the worthless," Ischomachus explains. In addition, he understands that the two most effective ways to elicit cooperation from servants are speech and reward: to some servants, a master need only say why "it is good for them to obey"; others, however, respond only

29 As W. W. Fortenbaugh explains, "Aristotle not only recognises the capacity of slaves to perceive reason. He also honours it and protests against withholding reasoned admonition and reason in general (1260b5-7). . . . Reason influences emotions and makes slaves more tractable. Hence a master should not punish a slave without offering a reason which prevents anger by justifying the punishment inflicted (Rhet. 1380b16-20). But offering a reason may be more than pragmatic and self-serving. It may also be giving a slave his due. For offering a reason involves acknowledging that slaves can follow reasoned admonition and judge for themselves whether or not a particular course of action is appropriate. . . . Slaves cannot put together reasoned arguments and cannot offer their master reasoned advice. But they can perceive their masters' [sic] reasons and can decide to follow them. To this extent they can partake of reason, so that Aristotle is on firm moral as well as psychological ground when he protests against refusing slaves reasoned admonition. To offer reasoned explanation is to respect a slave's cognitive capacity and to allow him to partake of reason as best he can"; see "Aristotle on Slaves and Women," in Ethics and Politics, vol. 2, Articles on Aristotle, ed. Jonathan Barnes, Malcolm Schofield, and Richard Sorabji (London: Gerald Duckworth, 1977), 137. Fortenbaugh's interpretation differs from mine in that he does not identify sunesis as the slave's capacity and suggests that Aristotle intends his argument to be merely theoretical (ibid., 136-37).

30 This suggests that, although (nonslavish) children have a greater potential for reasoning than slaves, they cannot understand reasoning as well as slaves. Hence natural slaves are capable of caring for children. At the same time, Aristotle warns that children may acquire vulgar habits from anything vulgar they hear or see ( $\mathrm{Pol}$ $1336 \mathrm{a} 41, \mathrm{~b} 2-3)$, thereby recommending that the best slaves or fully rational adults such as the parents care for the children.

31 This condition would allow those persons who might be mistakenly enslaved-because they were born from slavish parents-to win their freedom. (Nature does not prevent either slavish parents from bearing nonslavish offspring or nonslavish parents from bearing slavish offspring; Pol 1255b1-4.) Aristotle's provision for emancipation is not then an admission that all slaves, as such, can attain full reason (Barker, Political Thought, 365) but a recognition of the injustice that may result from nature's irregularity and a corrective to that injustice. 
to the prospect of getting something they want. What motivates servants varies, "some natures being hungry for praise as others for meat and drink." One who seeks his approval, Ischomachus treats "like a free man by making him rich; and ... as a gentleman." Finally, Ischomachus implies that he and his wife resort to punishment to make servants obey only when the servants are careless, and then they apparently only rebuke them or give them the inferior clothes and shoes when distributing such articles among their servants. ${ }^{32}$

Aristotle and Xenophon are saying, in contemporary terms, that "the relationship between master and natural servant . . . results in despotic rule in inverse proportion to the possession of reasoned speech by the ruled. Only if reasoned speech is wholly absent is the rule perfectly despotic." 33 They both present the use of force or punishment as a last resort or an exception to the way one should generally rule servants. Mastery seems primarily to be the art of rewarding-knowing when, how, whom, and with what to reward (NE 1107a6, 1138b20-25, 1141b27-28). ${ }^{34}$ It therefore requires justice (dikaiosunē) or prudence (phronessis) — the knowledge of and ability to effect what is good for another human being (NE 1130a3$4,1142 \mathrm{~b} 16,21,1143 \mathrm{~b} 21-22) .{ }^{35}$

\section{The Natural and Private STATUS OF SLAVERY}

One can discern four respects in which Aristotle believes slavery to be natural. Most obvious, slavery enables those who are more virtuous than slaves to attain moral and intellectual excellence, their natural end, by freeing them from necessary tasks ( $P o l$ 1253b24-25, 1254b25-26, 1255a19-21, b35-37; NE 1179a9-11). Slavery is in this respect a condition of virtue or freedom, as Arendt's account also observes. ${ }^{36}$ Second, slavery is natural because slaves

32 Xenophon, Oeconomicus, 444-45, 472-77; see also 468-69.

33 John F. Wilson, "Power, Rule and Politics: The Aristotelian View," Polity 13, no. 1 (1980), 89.

34 For Xenophon, see Oeconomicus, 474-75.

35 As Stephen R. L. Clark puts it, "the oikonomos, the head of the household exercising his good sense in its management, is a model for the phronomos [sic] no less than the statesman" (Aristotle's Man [Oxford: Clarendon, 1975], 210).

36 Human Condition, 30-31, 83 n. 9. 
are natural: some human beings can rule themselves only indirectly, by subjecting themselves to morally and intellectually superior human beings; ${ }^{37}$ others, wholly lacking in moral virtue, require superiors to take the initiative in showing them what is best for them. ${ }^{38}$ Aristotle is thus consistent, saying that both the practice of slavery and slaves are natural. Third, slavery is natural in that it helps a slave realize his potential or natural end as a human being. A slave, being alive, has of course a natural end for which he exists: "It is absurd to suppose that purpose is not present because we do not observe the agent deliberating" (Ph 199b27). As a slave, he learns skills and develops his inclination to belong to another into loyalty, honesty, and friendship. Indeed, he becomes less slavish. For slaves, then, slavery is not a condition for living a full life, it is that life. Fourth, mastery, what effects slavery, is natural in that it edifies a master. By caring for, befriending, training, and morally guiding a slave, a master exercises justice, temperance, and prudence. Strengthening the virtues of the free, mastery thereby facilitates their engagement in politics and philosophy. The benefits politics and philosophy yield are thus attributable in two indirect respects to the practice of slavery.

Whereas slavery ideally realizes a slave's potential, mastery does not maximize, but only enhances, a master's virtue. Nature itself qualifies the virtue mastery confers: ruling over inferiors, whether in private or in public, does not exercise all the virtues of a free person. What distinguishes mastery from forms of public rule and indeed defines it as private is that it creates, by bringing about the satisfaction of needs, opportunity to exercise all virtues or achieve excellence.

One scholar suggests that Aristotle, by claiming that "slavery makes politics and philosophy possible," may be implying a hope that "politics and philosophy can relieve man of his unnatural slavery to nature." 39 Those who are free to engage in politics and

37 Barker makes the same point at Political Thought, 370.

38 Some natural slaves identify themselves by voluntarily putting themselves in the service, and under the tutelage, of their superiors. As for the rest, their identification is made possible by their showing themselves to be unable to care for themselves. The naturally slavish cannot be identified by their appearance, including their race, because "matter does not produce difference" (Met 1058b3-7, Pol 1254b27-34).

39 Nichols, "Good Life," 176. 
philosophy because of slavery may come to see a way for everyone to live the good life - a way to bring into being a world without slavery or unjust domination, or, in another scholar's words, a world characterized by "political relationships" rather than "political rule." 40 This speculation, however, attributes too much optimism to Aristotle and does not account for the inclusion of slaves in the best regime (Pol 1328b19-20, 1329a35-36, 1330a25-30, 1334a2). We should conclude that Aristotle thinks there could be, with the help of politics and philosophy, not a regime without slavery but a regime with the right kind of slavery-a sort of private sponsorship and form of rule. For, although politics and philosophy may relieve us of our slavery to nature, they cannot alter the natural human hierarchy. Forms of rule, both public and private, remain indispensable.

40 Wilson, "Power, Rule and Politics," 96. "Political relationships," in contrast to "political rule," rest "neither on power or force, nor on command, but on discussion and persuasion" and can form only if "moral and intellectual virtue . . . are developed in due measure in each of [a political community's] members." 